\title{
THE SOCIAL RESPONSIBILITY OF TOURISM AND HOTEL ESTABLISHMENTS AND THEIR ROLE IN SUSTAINABLE TOURISM DEVELOPMENT IN AL-AHSA, SAUDI ARABIA
}

\author{
Thowayeb H. HASSAN* \\ King Faisal University, Department of Social Science, College of Arts, P.O. Box 380, Al Ahsa 31982, Saudi Arabia, e-mail: thassan@kfu.edu.sa \\ Helwan University, Faculty of Tourism and Hotel Management, P.O. Box 12612, Cairo, Egypt, e-mail: thowayeb.hassan@fth.helwan.edu.eg
}

\section{Hossam S. SHEHATA}

King Faisal University, Department of Social Science, College of Arts, P.O. Box 380, Al Ahsa 31982, Saudi Arabia, Alexandria University, Faculty of Tourism and Hotels, P.O. Box21526, Egypt, e-mail: hramadan@kfu.edu.sa

\author{
Mohammed EL-DIEF
}

Umm AL-Qura University, College of Business, Makkah Al Mukramah, Saudi Arabia, Helwan University, Faculty of Tourism and Hotel Management, P.O. Box 12612, Cairo, Egypt, e-mail: mmdief@uqu.edu.sa

\author{
Amany E. SALEM
}

King Faisal University, Department of Social Science, College of Arts, P.O. Box 380, Al Ahsa 31982, Saudi Arabia, e-mail: asalem@kfu.edu.sa Helwan University, Faculty of Tourism and Hotel Management, P.O. Box 12612, Cairo, Egypt, e-mail: amany.ibrahim@fth.helwan.edu.eg

\begin{abstract}
Citation: Hassan, T.H., Shehata, H.S., El-Dief, M., \& Salem, A.E. (2020). THE SOCIAL RESPONSIBILITY OF TOURISM AND HOTEL ESTABLISHMENTS AND THEIR ROLE IN SUSTAINABLE TOURISM DEVELOPMENT IN AL-AHSA, SAUDI ARABIA. GeoJournal of Tourism and Geosites, 33(4spl), 1564-1570. https://doi.org/10.30892/gtg.334spl18-609
\end{abstract}

\begin{abstract}
This study aims to assess the impact of implementing corporate social responsibility (CSR) practices on sustainable tourism development in Al-Ahsa city, Saudi Arabia. A survey was electronically distributed to the managers of hotels and travel agencies in Al-Ahsa City. A total of eight CSR strategies, including information analysis, compensation, system, delegation, prevention, education, regulation, and marketing, were extracted from the literature, and their effects on overall, economic, ecological, and social sustainability were investigated in hotels and tourism establishments. The results showed that promoting CSR adoption (marketing) and providing sustainability-related educational materials to customers were the most influential CSR practices on sustainability (mean scores \pm SD were $13.75 \pm 1.73$ and $12.82 \pm 1.98$ out of 15 , respectively). Sustainable development of hospitality and tourism corporates could be enhanced by implementing marketing and educational CSR practices, which ultimately support the rising trend of sustainable tourism in the Kingdom.
\end{abstract}

Key words: Corporate social responsibility, sustainability, travel and tour operators, tourism industry, Saudi Arabia

$* * * * * *$

\section{INTRODUCTION}

Social responsibility has become one of the contemporary core activities of the corporates, and many social responsibility issues have fundamentally become corporate issues that need to be addressed effectively. Traditionally, corporate social responsibility (CSR) was used to assess the impact of business on the environment and society as a matter of business ethics and stewardship principles. Subsequently, in the mid-twentieth century, Levitt (1958) and Friedman (1970) concluded a revolutionary aspect signifying that the responsibility of companies could maximize the profits of their owners and shareholders. With the recognition of the stakeholder theory, multiple economists had emphasized that CSR was a rational justification tool for "doing good" (Mcwilliams and Siegel, 2001), and it could be an invaluable source of innovation, opportunity, and competitive advantage (Porter and Kramer, 2006). These cumulative concepts have formulated the current comprehensive notion of CSR: the voluntary (beyond compliance) contributions of a corporate to diverse environmental, social, and ethical concerns (Moon et al., 2009). Other commonly used synonyms of CSR entail business ethics, corporate social performance, corporate citizenship, and corporate philanthropy. However, still there is no consensus definition of CSR.

Interestingly, the strategic plans of organizations' responsibilities entail their commitment to human and ecological behaviors. Corporates should meet such a need in the context of the present generation without compromising the prospected needs of future generations (Baumgartner and Rauter, 2017). In other words, the present generation should be aware that future generations would have better standards of existence as compared to theirs. Therefore, current efforts should aim at creating a suitable environment that leads to sustainable development. The concept of sustainability, which assures an efficient harmony between humans and nature without an ecological disruption, can be achieved via several actions in the strategic development (Harjoto and Salas, 2017). These actions can broadly be compartmentalized into environmental, economic, and social pillars in order to tackle issues pertinent to the planet, money, and people respectively (Rego et al., 2015). Although these pillars are apparently separated, they are holistically associated to attain the goals of many national standards and certification themes. Indeed, the economy is an essential part of the society, and the latter is a constituent part of the larger environment (Montiel, 2008). This way, business corporations could be transformed into sustainable institutions which would benefit from the business itself besides providing significant values to the society as well as the environment.

Based on the aforementioned principles, companies have started targeting the three pillars of sustainability, and hotels and travel agencies are no exception. In the hotel and tourism industry, thanks to globalization, the number of daily travelers worldwide is far different than that in the past. The lack of available energy resources and the growing environmental impact of these industries have prompted urgent actions by business operators to support sustainability management systems (Hughes and Scheyvens, 2018). Notwithstanding the instability of the renewable energy supply and the need to improve its functions, hotel operators have been increasingly acknowledging the use of 
renewable energy and the implementation of energy conservation systems. Additionally, travel companies, which act as intermediates between tourism businesses and tourists, have adopted active approaches towards sustainability with the purpose of maintaining long-term survival in the destination (Almunawar et al., 2012). While the need for sustainable tourism has become urgent with the explosive growth in the tourism industry in recent years worldwide (Saarinen, 2014), there exists a significant gap in the available research which frames the main drivers of sustainability, including CSR. Paskova and Zelenka (2019) have recently overviewed the conceptual dimensions of CSR that might impact sustainable activities, and they categorized CSR practices into eight main categories, which include information and analysis, system activities, compensation, delegation, prevention, customer education, regulation, and marketing activities. As far as other countries are concerned, evidence regarding the impact of CSR practices on corporate sustainability in Saudi Arabia remains derived from the academic theories, since to the best of our knowledge, there are no published articles which investigated such an important topic. Concomitantly, academic notions should basically be established based on real-life tests of validity and internal consistency in a given country. Of note, the impact of CSR on sustainability can be ideally expressed by the ultimate decision makers, namely the corporates' general managers. Managerial perceptions are important to understand, since they would eventually reflect CSR directives and the ways of implementation. As such, the present study aimed to assess corporate general managers' perceptions regarding the effects of implementing evidence-based CSR approaches on the sustainable development of hotels and travel agencies located in Al-Ahsa city, Saudi Arabia.

\section{LITERATURE REVIEW}

During the past decade, various studies have established that there was a significant global change in CSR and strategic corporate management, which commits these corporates to sustainable development, including the ecological, economical, and ethical sectors (Abram and Jarzabek, 2016; Tepelus, 2019). Indeed, consistent with the international standard of social responsibility published by the International Organization for Standardization (ISO), CSR is defined as the responsibility of a given corporate for the effects of its activities and decisions on different societal and environmental aspects through an ethical behavior that would mediate sustainable development, including the welfare of the society, considering stakeholders' expectations, the applicability to laws, and its organizational integration (Moratis and Cochius, 2017). In the tourism and hospitality industries, the concept of social responsibility can be implemented via multiple strategic approaches, which were thoroughly reviewed by Paskova and Zelenka (2019). For example, the effects of tourism subjects' performance on society, sustainability, and the environment represent an integral part of the information and analytical approach. Particularly, sustainability monitoring of the environmental footprints, such as the ecological and carbon footprints, is a common approach performed by hotel chains (Cadarso et al., 2016; Abeydeera and Karunasena, 2019; Eskerod et al., 2019). In the instance of negative tourism impacts, the compensation approach is implemented either at the point of origin (i.e. reforestation in the vicinity of a deforested area for tourism infrastructure) or the establishment of a publicly beneficial project in another appropriate region (Landau, 2020; Bello and Kamanga, 2020; Dube and Nhamo, 2020). A detailed description of the different approaches to CSR implementation is listed in Table 1.

Table 1. Approaches to the implementation of the CSR activities by tourism companies (Source: Adapted from Paskova and Zelenka, 2019)

\begin{tabular}{|l|l|}
\hline \multicolumn{1}{|c|}{ Approach } & \multicolumn{1}{c|}{ Description } \\
\hline $\begin{array}{l}\text { Information } \\
\text { and analytics }\end{array}$ & $\begin{array}{l}\text { Monitoring sustainability indicators (i.e. ecological footprints and non-financial reports) and facilitating the availability of data related to } \\
\text { expected and real effects of these indicators on the society. }\end{array}$ \\
\hline System & $\begin{array}{l}\text { The application of the international standards and total quality management methods in the implementation of changes in the management } \\
\text { of the tourism companies and hotels. }\end{array}$ \\
\hline Compensation & This approach means compensating for the negative consequences of tourism activities, such as deforestation for construction of tourism activities. \\
\hline Delegation & $\begin{array}{l}\text { Tourism establishments delegate responsibilities to their clients (visitors or guests). For example, financial delegation means a complete } \\
\text { inclusion of social and environmental costs of tourism into the price calculation of a given tourism service or product. }\end{array}$ \\
\hline Prevention & $\begin{array}{l}\text { Tourism companies endeavor to prevent generation of adverse environmental or social impacts throughout the product lifecycle, even at } \\
\text { the price of increasing the cost of the product. }\end{array}$ \\
\hline Education & Providing educational materials to support the sustainable patterns of customers' behaviors. \\
\hline Regulation & Setting up regulatory actions in the tourism sector, such as emission limits and carrying capacity. \\
\hline Marketing & $\begin{array}{l}\text { Promoting the favorable outcomes attained by the implementation of CSR activities and commitments to their application (e.g. promoting } \\
\text { environmental certification). }\end{array}$ \\
\hline
\end{tabular}

\section{CSR and Corporate Sustainability in the Hospitality Industry}

In the hospitality industry, CSR relies fundamentally on the availability of natural resources at a tourism destination, where such resources represent a primary asset and a major feature, which is influenced by potential overexploitation (Karim and Islam, 2020; SerraCantallops et al., 2018). It is, therefore, imperative to ascertain adequate tightening of the relevant regulations besides incorporating the tourism industry in efforts pertaining to environmental conservation. Indeed, hotel chains have significant roles in the implementation of all arms of social responsibility via their contribution in employment and income (Liu et al., 2017; Jamal Mohammad et al., 2020) in addition to their social and environmental effects (González-Rodríguez et al., 2019). However, it seems that a considerable proportion of CSR activities in hotels is primarily focused on promoting the health and safety of guests and employees, respecting the ethical and social norms in the society, and reducing the negative effects on the environment (Abram and Jarzabek, 2016; Ghaderi et al., 2019).

In general, the impact of CSR policies on hotel performance and sustainable development could be corroborated in the literature. For instance, CSR has influenced loyalty and satisfaction via direct and indirect mechanisms as revealed in a survey of Chinese hotel consumers (Liu et al., 2019). Similarly, CSR activities have markedly influenced the reputation of hotels and travel agencies in several countries, such as the United States (Kim and Kim, 2016), Argentina (Bianchi et al., 2019), and Malaysia (Mohammed and Rashid, 2018). The economic performance, as a major component of sustainability, has also been positively associated with CSR activities (Mariño-Romero et al., 2020, García-Pozo et al., 2019). Recently, Mariño-Romero et al. (2020) have indicated important roles of implementing CSR policies on the revenue per available room in an analytical study involving Spanish hotels. Actually, such evidence underscores CSR adoption as a fundamental strategy in order to build robust sustainable development plans over long-term periods in the hotel sector.

\section{CSR and Corporate Sustainability in the Tourism Industry}

The tourism industry has rapidly evolved in recent years, especially thanks to the integration of technology in the buying habits of consumers and tourism distribution channels. Sustainable development in tourism has been largely ignored for several years, and the implications of these developmental aspects for environmental management policies at various destinations have been scarcely investigated 
(Cotterell et al., 2019). Like other industries, the perceptions and moral philosophies of professionals in the tourism industry are significantly variable, which could be explained by cultural differences. However, tour operators, internet operators, and travel agencies would expectedly be engaged in activities as implied by the frameworks of the United Nations Sustainability Development Goals (Tepelus, 2019). This way, tour operators can move towards sustainable tourism via internal management, supply chain management, product development, enhancing customer relations, and improving the cooperation with destination (Jermsittiparsert et al., 2019; Richards and Font, 2019).

In a multinational analysis of tour operators in the United States, Canada, Europe, and Australia (Strasdas, 2019), the authors specified that CSR activities were primarily associated to environmental aspects, such as waste management strategies and minimizing resource use, and they prevailed over socio-cultural responsibility topics. These companies tended to transmit their commitment and enthusiastic behaviors to their customers, which increased their satisfaction. Based on these findings, tour operators are required to implement active actions in their economic, environmental, and social performance to guide their consumers who seek to support sustainable strategies. In Romania, it has been found that tour operators and travel agencies were highly committed to CSR practices (Marin-Pantelescu et al., 2019). Nevertheless, the main objective of such commitment was to support corporate image rather than the implementation of fundamental sustainability goals. Likewise, previous investigations have repeatedly opined the view that tour operators are concerned with organizational benefits and consume natural resources without conserving them (Richards and Font, 2019; Hamid et al., 2020). Recently, representative professionals of tour operators in Hong Kong have expressed varied opinions regarding social and environmental responsibilities, emphasizing that the government was the most influential stakeholder to promote responsibility in tour operation business (Otoo et al., 2020).

\section{MATERIAL AND METHODS}

\section{Study Design and Data Collection}

A survey-based study was conducted in Al-Ahsa city during the period from June 01 to August 31, 2020. Al-Ahsa city is located in AlAhsa Governorate, which is the largest governorate in the Eastern Province in Saudi Arabia. Thanks to its geographical location, Al-Ahsa represents an important link between the Arabian Peninsula and the external world. It contains one of the largest palm oases worldwide (AlAhsa Oasis). In 2019, the Arab Ministerial Council on Tourism named Al-Ahsa as the "Capital of Arab Tourism" (Alarabiya.Net, 2018). According to the Saudi Commission for Tourism and National Heritage (SCTH), there are 8 hotels, including 3-, 4-, and 5-star hotels, and a total of 30 travel agencies in the city. Such organizations represent the target sample of the present study. Therefore, an electronic survey was distributed to the e-mail addresses of all organizations ( $n=38)$, of which 28 completed surveys ( 6 hotels and 22 travel agencies) were received and analyzed, accounting for a response rate of $73.7 \%$. The e-mail addresses of all corporates were obtained from the SCTH website.

\section{Study Questionnaire}

A structured questionnaire was used to collect data from the respective administration officers in each organization. The questionnaire consisted of three major domains: 1) organization data, including organization type (hotel or travel agency), address, category, ownership, and type of management (local or foreign); 2) patterns of CSR implementation, including the responsible department for CSR administration, the reasons for which CSR had been implemented, the types of CSR practices which had been embraced, the methods of raining the employees' awareness regarding social responsibility issues, and whether the organization has regularly been preparing annular reports regarding CSR practices; and 3) the perceived impact of the eight CSR domains (Table 1) on the aspects of developmental sustainability, including the economic, social, and environmental aspects. The items of the first and second domains were collected by conducting a thorough review of the relevant literature. CSR approaches of the third domain were obtained from a comprehensive overview of CSR activities in the tourism and hospitality industries (Paskova and Zelenka, 2019). The responses of such a domain were indexed in a 5-point Likert scale, ranging from 1 (no influence) to 5 (highly influential). The definitions of CSR practices as well as sustainability domains were clearly provided to all participants prior to completing the questionnaire form.

Table 2. Characteristics of the included establishments and their patterns of social responsibility application

\begin{tabular}{|c|c|c|c|}
\hline Category & Subcategory & Frequency & Percent \\
\hline \multirow{7}{*}{ Type of establishment } & Hotel & 6 & 21.4 \\
\hline & 3 stars & 1 & 16.7 \\
\hline & 4 stars & 2 & 33.3 \\
\hline & 5 stars & 3 & 50 \\
\hline & Travel Agency & 22 & 78.6 \\
\hline & $\mathrm{A}$ & 13 & 59.1 \\
\hline & $\mathrm{B}$ & 9 & 40.9 \\
\hline \multirow{2}{*}{ Management Type } & Local Administration & 19 & 67.9 \\
\hline & Foreign Administration & 9 & 32.1 \\
\hline \multirow{2}{*}{ Ownership } & Private & 28 & 100 \\
\hline & Government & 0 & 0 \\
\hline \multirow{3}{*}{ Department responsible for CSR } & Public relations & 12 & 42.9 \\
\hline & Marketing & 15 & 53.6 \\
\hline & Separate Department & 1 & 3.6 \\
\hline Does your tourism establishment evaluate CSR activities? & Yes & 28 & 100 \\
\hline \multirow{3}{*}{$\begin{array}{l}\text { Does your tourism establishment prepare annual report for social } \\
\text { responsibility practices? }\end{array}$} & Yes & 9 & 32.1 \\
\hline & No & 19 & 67.9 \\
\hline & No & 0 & 0 \\
\hline
\end{tabular}

\section{Statistical Analysis}

The Statistical Package for Social Sciences version 26.0 (SPSS Inc., Chicago, IL, USA) was utilized to conduct the statistical analysis. The reliability of different domains of the questionnaire was assessed using a Cronbach's alpha ( $\alpha$ ). Quantitative and qualitative variables were presented as frequencies and percentages or means and standard deviation (SD). An overall effect score was computed for each CSR domain by summing up the scores of Likert responses (ranging from 1 to 5) regarding the impact of CSR on ecological, economic, and social sustainability aspects. Therefore, the overall effect score ranged between 1 (no effect) to 15 (complete effect). The normality of the overall effect scores in each domain as well as the Likert scores of each sustainability aspect was assessed numerically using the KolmogorovSmirnov Test and the Shapiro-Wilk test, revealing P values of $<0.0001$ for both tests. Subsequently, nonparametric tests were employed in 
the analysis. Establishment-based differences in the effect scores (between hotels and travel agencies) were investigated using a Mann Whitney test. Statistically significant differences in the effects of CSR practices on sustainable tourism development were tested using the rank-based test, Kruskal-Wallis H test, using CSR groups $(n=8)$ as the grouping variable. A post hoc analysis was performed to identify the distinct groups with statistically significant differences, whenever available. All results were categorized according to the type of the establishment (hotel or travel agency). A P value of $<0.05$ was considered to reject the null hypothesis.

\section{RESULTS AND DISCUSSIONS}

General characteristics and patterns of CSR implementation in the included corporates

The responses of 28 corporate managers were analyzed (6 hotels and 22 travel agencies). Five-star hotels represented $50 \%$ of the included hotels, while class A travel agencies comprised of 59.1\% of the total travel corporates. All the establishments were managed by the private sector, and they have been implementing regular CSR activities. However, about one-third of the corporates (32.1\%) had previously prepared annual reports for such activities (Table 2).

Regarding questions with multiple responses, growing corporate's income was the most frequently reported reason for CSR implementation $(27.6 \%)$, followed by attracting customers' attention (Figure 1A). Management briefings were the most commonly used method to raise employees' awareness regarding CSR (47.6\%, Figure 1B). Importantly, the majority of participants declared that marketing and information analysis were used frequently as methods for CSR (21.8\% and $17.6 \%$ respectively, Figure 1C).

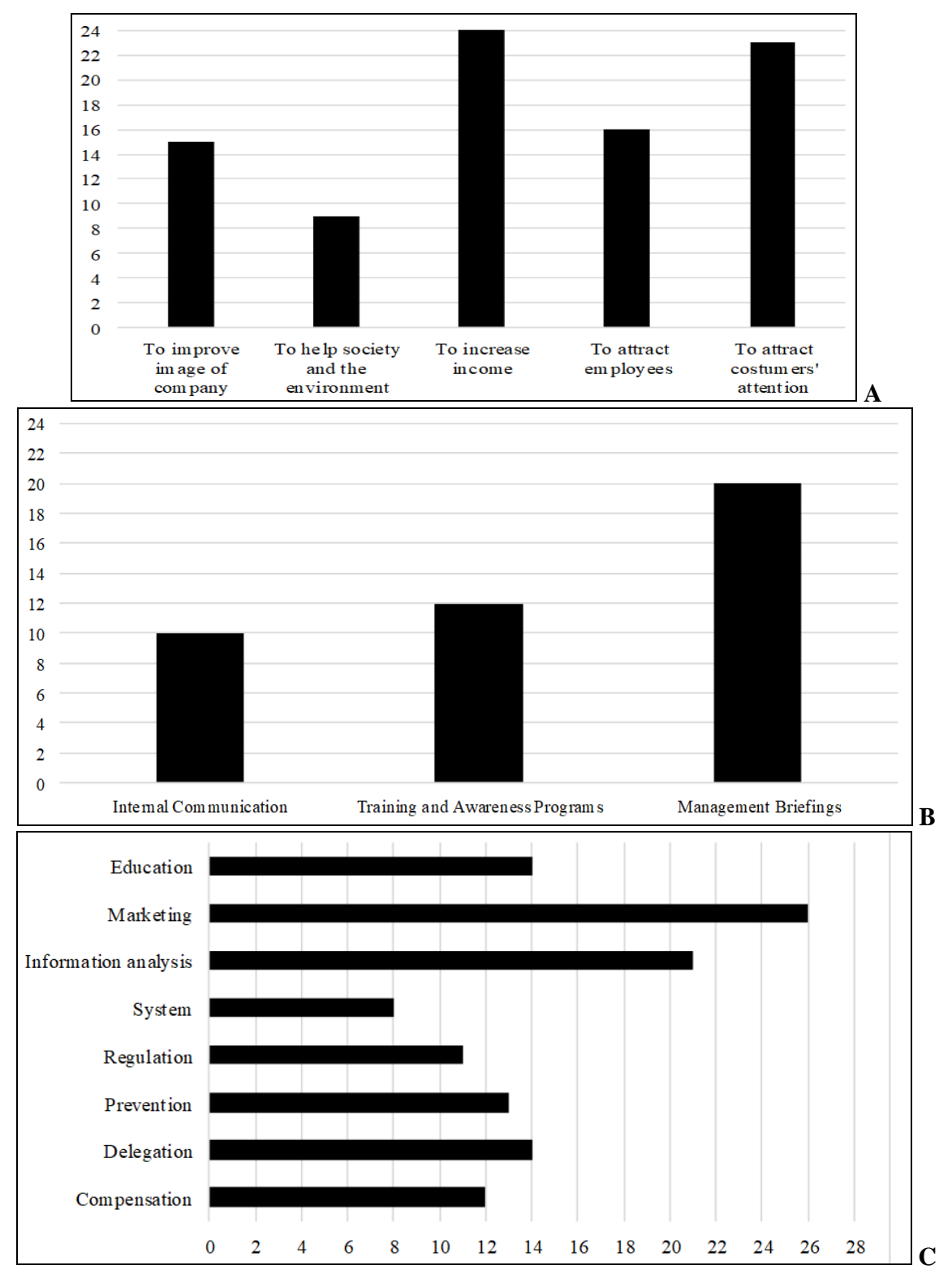

Figure 1. The responses of participants to multi-response questions regarding the reasons for which CSR has been implemented (A), methods of raising awareness regarding CSR (B), and the types of implemented CSR practices (C)

\section{Corporate-based differences in the effects of CSR practices on sustainability domains}

Effect scores across all the establishments have been demonstrated in Table 3. As perceived by the participants, marketing was the most impactful CSR activity (mean score \pm SD was $13.75 \pm 1.73$ ) followed by education (mean score \pm SD was $12.96 \pm 1.79$ ) and delegation (mean score \pm SD was $12.82 \pm 1.98$ ). While sustainability was significantly more affected by preventive CSR practices in hotels than travel agencies $(13.17 \pm 1.83$ versus $11.05 \pm 2.08, \mathrm{P}=0.036)$, marketing had greater effects on sustainability among travel agencies as compared to hotels $(14.09 \pm 1.51$ versus $12.5 \pm 2.07, \mathrm{P}=0.035)$. 
Thowayeb H. HASSAN, Hossam S. SHEHATA, Mohammed EL-DIEF, Amany E. SALEM

Table 3. Scores of the effect of implementing CSR activities on sustainable tourism development

\begin{tabular}{|l|c|c|c|c|}
\hline \multicolumn{1}{|c|}{ CSR activity } & Overall & Hotel $(\mathrm{n}=6)$ & Travel Agencies $(\mathrm{n}=22)$ & $\mathrm{P}$ \\
\hline Information analysis & $12.18 \pm 2.02$ & $11.67 \pm 1.21$ & $12.32 \pm 2.19$ & 0.444 \\
\hline Compensation & $11.29 \pm 2.52$ & $12.67 \pm 1.86$ & $10.91 \pm 2.58$ & 0.15 \\
\hline System & $11.46 \pm 2.05$ & $12.33 \pm 1.21$ & $11.23 \pm 2.18$ & 0.288 \\
\hline Delegation & $12.82 \pm 1.98$ & $13.5 \pm 1.97$ & $12.64 \pm 1.99$ & 0.265 \\
\hline Prevention & $11.5 \pm 2.19$ & $13.17 \pm 1.83$ & $11.05 \pm 2.08$ & 0.036 \\
\hline Education & $12.96 \pm 1.79$ & $12 \pm 1.67$ & $13.23 \pm 1.77$ & 0.088 \\
\hline Regulation & $11.04 \pm 1.77$ & $12.33 \pm 1.37$ & $10.68 \pm 1.73$ & 0.067 \\
\hline Marketing & $13.75 \pm 1.73$ & $12.5 \pm 2.07$ & $14.09 \pm 1.51$ & 0.035 \\
\hline
\end{tabular}

*p value of the difference in ranks of Mann Whitney test between hotels and travel agencies

As far as the hospitality industry is concerned, implementing preventive responsible practices has proven effective to enhance destination sustainability. For example, in Sri Lanka, responsible tourism and hotel activities have led to significant improvements in the quality of life of individuals in destination communities and have improved the experience of tourists while reducing the negative economic, social, and environmental impacts (Sariskumar and Bhavan, 2018). It has been shown that implementing environmentally-friendly preventive actions by hotels would enhance energy efficiency and waste management at the corporate level (Kularatne et al., 2019). Campbell et al. (2015) established that a price increase justified by preventing the adverse impacts of fair trade was generally accepted by the customers. The authors specified that additional investments in preventive social commitments associated with a price increase would not impact purchase intentions because customers feel that they are contributing to something good (Campbell et al., 2015). Therefore, preventive CSR practices should be adopted by tourism corporates to support destination sustainability and improve the quality of life of local residents. On the other hand, the effect of the educational approach was appreciated by managers in our study. Previous evidence showed also a positive association between providing sustainability education for guests and the number of guest visits, revenues, and guest satisfaction (Walsh et al., 2017). Fostering environmental education has also proven beneficial in a Taiwanese study, yet the lack of commitment, owing to uncertainty regarding its consequences, was a significant barrier to regular green education (Yeh et al., 2016). To the best of our knowledge, the present study is the first to demonstrate the impact of customers' education on tourism sustainability in Saudi Arabia, emphasizing the need of focusing on a relatively novel trend for hoteliers regarding green education of customers.

\section{CSR-based differences in the effects of CSR practices on sustainability domains}

Taking into consideration the differences across CSR domains and focusing on the responses provided by hotel managers, no significant differences were found in the mean ranks of the perceived effects on overall sustainability as well as the economic, social, and ecological aspects of sustainability (Table 4). However, the mean ranks of the effects on sustainability differed significantly across CSR practices implemented by travel agencies. In addition, statistically significant differences were found in the effects of CSR practices on all subdomains of sustainability, including economic $(\mathrm{P}=0.001)$, social $(\mathrm{P}<0.001)$, and ecological $(\mathrm{P}<0.001)$ aspects.

Table 4. CSR-based differences in the mean ranks of the effects of CSR activities on sustainability domains across the whole sample, hotels, and travel agencies

\begin{tabular}{|c|c|c|c|c|c|c|c|c|}
\hline \multirow[t]{2}{*}{ Parameter } & \multicolumn{4}{|c|}{ Hotels } & \multicolumn{4}{|c|}{ Travel Agencies } \\
\hline & Overall & Economic & Social & Ecological & Overall & Economic & Social & Ecological \\
\hline \multicolumn{9}{|c|}{ Mean Ranks* } \\
\hline Information analysis & 17.25 & 22.00 & 21.50 & 15.33 & 94.61 & 91.34 & 99.23 & 90.98 \\
\hline Compensation & 26.00 & 23.25 & 28.50 & 24.00 & 66.80 & 62.20 & 76.14 & 77.89 \\
\hline System & 22.58 & 22.00 & 25.67 & 23.17 & 70.95 & 73.50 & 69.55 & 80.68 \\
\hline Delegation & 32.75 & 32.00 & 32.00 & 28.00 & 101.05 & 107.23 & 99.18 & 87.95 \\
\hline Prevention & 29.92 & 26.17 & 25.00 & 32.67 & 65.43 & 76.27 & 71.64 & 70.75 \\
\hline Education & 20.08 & 19.08 & 23.83 & 21.67 & 114.91 & 101.68 & 107.95 & 113.68 \\
\hline Regulation & 23.17 & 19.50 & 19.17 & 29.50 & 56.95 & 75.61 & 64.68 & 61.32 \\
\hline \begin{tabular}{l|l} 
& Marketing \\
\end{tabular} & 24.25 & 32.00 & 20.33 & 21.67 & 137.30 & 120.16 & 119.64 & 124.75 \\
\hline Degree of Freedom & 7 & 7 & 7 & 7 & 7 & 7 & 7 & 7 \\
\hline $\mathrm{P}$ value & 0.585 & 0.424 & 0.687 & 0.403 & $<0.0001$ & 0.001 & $<0.0001$ & $<0.0001$ \\
\hline
\end{tabular}

*Values obtained by a Kruskal-Wallis H Test

To investigate particular CSR practices which have mediated such differences, pairwise comparisons were carried out, and the significant effects were adjusted by the Bonferroni correction for multiple tests. Results revealed consistently higher effects of marketing on overall sustainability as compared to CSR practices pertinent to regulation (rank difference $=80.34, \mathrm{P}<0.0001$ ), prevention (rank difference $=$ 71.86, $\mathrm{P}<0.0001$ ), compensation (rank difference $=70.5, \mathrm{P}<0.0001$ ), and the corporate system (rank difference $=66.34, \mathrm{P}<0.0001$ ). As far as subgroups analysis of sustainability domains is concerned, marketing practices were the most influential CSR parameters, where they were superior to compensation and system practices on economic sustainability (rank differences $=57.96$ and $46.66, P=0.002$ and $\mathrm{P}=0.043$ respectively), regulation, system, and prevention practices on social sustainability (rank differences $=54.96,50.09$, and $48.00, \mathrm{P}=0.003$, 0.013 , and 0.022 respectively), and compensation and prevention practices on ecological sustainability (rank difference $=46.86$ and $54.00, P$ $=0.029$ and 0.004 respectively). Similarly, several examples of implementing the marketing approach have been demonstrated in the literature. For instance, promoting environmental certification, defined as providing documented assurance that a service, product, or corporate adheres to a particular standard, has been cited as a strong factor that could alleviate the negative social and environmental impacts and corroborate that the establishment is held accountable to stakeholders (Essawy, 2019). In the literature, it has been shown that greening the marketing strategy of businesses would help implement the managemental activities for identifying and satisfying customer needs in both profitable and sustainable ways (Chung, 2020; Yadav et al., 2016). This way, certified travel agencies are able to gain significant competitive advantages. The most significant success story has been pointed out by the Blue Flag Campaign, the first environment ecolabel which is specifically awarded to beaches and marina in European coastal zones. Since its first introduction in 1987, the Blue Flag Campaign has been adopted in 2,500 European beaches, and many non-European countries have implemented specific programs to raise awareness about the Campaign (Fraguell et al., 2016). Generally, ecolabels help impart a social reputation of travel agencies and tour operators; even unemployed persons have preferred working for eco-labelled establishments (Y1lmaz et al., 2019). In Turkey, the environmental views of travel agencies were 
evident, where corporate managers emphasized the significance of environmental management criteria and the barriers to environmental protection. Nevertheless, the participants did not translate their perceptions to real-life environmental practices, since such agencies did not employ any environmental programs or allocate specific budgets for environmental protection (Erdoğan, 2012). In our study, we did not confirm whether tourism corporates had CSR practices in place, thus we could not assess their potential effects on investment and sustainability.

Based on the aforementioned findings, the influence of marketing and educational approaches has been appreciated by corporate managers, while the effects of other approaches were less acknowledged. Although the relevant data of the impact of corporate performance on sustainability aspects were readily available (the information and analytical approach) as declared by a considerable proportion of participants (Figure 1C), the implementation of sustainability monitoring was not effective on the sustainable development. Notwithstanding the high impact of the delegation approach on sustainability of hotels as reported by hoteliers, the difference between the effect of such an approach and others did not reach statistical significance. Once again, the small number of hotels was an important limitation that needs to be addressed in future studies by including hotels from different parts across Saudi Arabia.

\section{CONCLUSION}

Multiple national and international tourism corporations have paid great attention to CSR practices in order to support the welfare of local communities, protect the environment, and provide fair working conditions for their employees. In Al-Ahsa city, CSR was commonly implemented by travel agencies and hotels. Marketing and preventive CSR practices were the most significant approaches on aspects of sustainable development in the tourism sector as indicated by the managers of tourism and hospitality establishments. Sustainability management, including marketing of green practices and providing sustainability education to customers, should be emphasized in hospitality research not only in Al-Ahsa city, but also in studies conducted in other regions in the Kingdom. This would enhance corporate's image, support customer loyalty, and assure the adoption of environment-friendly practices at the destination. Future studies in Al-Ahsa city are needed, focusing the impact of CSR marketing methods, preventive practices, and educational responsible activities on customers' satisfaction that might lead to effective sustainable actions.

\section{Strengths, limitations, and future implications}

In addition to the small sample size of hotels, other limitations were apparent in the current analysis. Firstly, the survey-based design might have impacted statistical differences among different parameters of sustainability and CSR practices. Secondly, the obtained self-reported data are subject to response bias, meaning that the respondents might have tended to provide answers based on socially- and economically-acceptable criteria to meet the ideal requirements of CSR implementation. Thirdly, the study setting was limited to one region that might limit the generalizability of results. Therefore, we suggest conducting multi-regional business analytical studies which depend on evidence-based data of the impact of each CSR strategy on a given pillar of sustainable development, such as corporate profits and customer's behaviors. However, within the paucity of available data on tourism and hospitality locally, we believe that the outcomes of the present study provide a cornerstone for future business plans and a framework for CSR strategies that have to be given due consideration by travel agencies and hotels in Al-Ahas city. In essence, green marketing should be stressed in the tourism and hospitality sectors, since it has a moderating effect on customer behavior intentions towards the corporate, particularly for those with high environmental consciousness (Martinez Garcia De Leaniz et al., 2018). Besides, green practices would positively influence the corporate image (Yadav et al., 2016). Hotel operators and managers of travel agencies are encouraged to support technical solutions and innovations aiming at promoting the activities of environmental support to gain competitive advantage while preserving their energy resources and building robust trust with consumers. It is also recommended to adopt responsible activities to prevent the adverse environmental and societal impacts of tourism and hospitality, even at the price of cost increase. Conducting similar studies in other regions in the Kingdom would provide valuable insights into sustainable tourism development in a country with rich cultural heritage and a great number of archaeological sites. Eventually, this would support the SCTH's "TAKAMUL" program, which aims to unlock the tourism sector's potential to achieve sustainable developmental targets in line with vision 2030 (Durugbo et al., 2020).

Acknowledgement: The authors extend their appreciation to the Deputyship for Research \& Innovation, Ministry of Education in Saudi Arabia for funding this research work through the project number IFT20105.

\section{REFERENCES}

Abeydeera, L.H.U.W., \& Karunasena, G. (2019). Carbon Emissions of Hotels: The Case of the Sri Lankan Hotel Industry. Buildings, 9(11), 227. https://doi.org/10.3390/buildings9110227

Abram, M., \& Jarzabek, J. (2016). Corporate social responsibility in hotel industry: environmental implications. J Ecocycles, 2(2), 9-16. https://doi.org/10.19040/ecocycles.v2i2.51

Almunawar, M.N., Anshari, M., \& Susanto, H. (2012). Crafting strategies for sustainability: how travel agents should react in facing a disintermediation. Operational Research, 13(3), 317-342. https://doi.org/10.1007/s12351-012-0129-7

Baumgartner, R.J., \& Rauter, R. (2017). Strategic perspectives of corporate sustainability management to develop a sustainable organization. Journal of Cleaner Production, 140, 81-92. https://doi.org/10.1016/j.jclepro.2016.04.146

Bello, F.G., \& Kamanga, G. (2020). Drivers and barriers of corporate social responsibility in the tourism industry: The case of Malawi. Development Southern Africa, 37(2), 181-196. https://doi.org/10.1080/0376835X.2018.1555028

Bianchi, E., Bruno, J.M., \& Sarabia-Sanchez, F.J. (2019). The impact of perceived CSR on corporate reputation and purchase intention. European Journal of Management and Business Economics, 28(3), 206-221. https://doi.org/10.1108/ejmbe-12-2017-0068

Cadarso, M.Á., Gómez, N., López, L.A., \& Tobarra, M.Á. (2016). Calculating tourism's carbon footprint: measuring the impact of investments. Journal of Cleaner Production, 111, 529-537. https://doi.org/10.1016/j.jclepro.2014.09.019

Campbell, C.L., Heinrich, D., \& Schoenmüller, V. (2015). Consumers' reaction to fair trade motivated price increases. Journal of Retailing and Consumer Services, 24, 79-84. https://doi.org/10.1016/j.jretconser.2015.02.005

Chung, K.C. (2020). Green marketing orientation: achieving sustainable development in green hotel management. Journal of Hospitality Marketing \& Management, 29(6), 722-738. https://doi.org/10.1080/19368623.2020.1693471

Cotterell, D., Hales, R., Arcodia, C., \& Ferreira, J.A. (2019). Overcommitted to tourism and under committed to sustainability: the urgency of teaching "strong sustainability" in tourism courses. Journal of Sustainable Tourism, 27(7), 882-902. https://doi.org/10.1080/09669582.2018.1545777

Dube, K., \& Nhamo, G. (2020). Sustainable Development Goals localisation in the tourism sector: lessons from Grootbos Private Nature Reserve, South Africa. GeoJournal, 1-18. https://doi.org/10.1007/s10708-020-10182-8

Durugbo, C.M., Al-Jayyousi, O.R., \& Almahamid, S.M. (2020). Wisdom from Arabian creatives: Systematic Review of Innovation Management Literature for the Gulf Cooperation Council (GCC) Region. International Journal of Innovation and Technology Management. https://doi.org/10.1142/S0219877020300049

Erdoğan, N. (2012). Environmental views and practices in tourism industry: a study on travel agency managers. J İsletme Araştırmaları Dergisi, 4(2), 52-65.

Eskerod, P., Hollensen, S., Morales-Contreras, M.F., \& Arteaga-Ortiz, J. (2019). Drivers for Pursuing Sustainability through IoT Technology within High-End Hotels-An Exploratory Study. Sustainability, 11(19), 5372. https://doi.org/10.3390/su11195372 
Essawy, T.M. (2019). Assessing the Application of Corporate Social Responsibility in Egyptian Travel Agencies. Journal of Association of Arab Universities for Tourism and Hospitality, 17(2), 90-109. https://doi.org/10.21608/jaauth.2019.92261

Fraguell, R.M., Martí, C., Pintó, J., \& Coenders, G. (2016). After over 25 years of accrediting beaches, has Blue Flag contributed to sustainable management? Journal of Sustainable Tourism, 24(6), 882-903. https://doi.org/10.1080/09669582.2015.1091465

Friedman, M. (1970). The Social Responsibility of Business Is to Increase Its Profits. The New York Times Magazine Retrieved from http://umich.edu/ thecore/doc/Friedman.pdf. Last Access: August 27, 2020

García-Pozo, A., Mondéjar-Jiménez, J., \& Sánchez-Ollero, J. L. (2019). Internet's user perception of corporate social responsibility in hotel services. Sustainability, 11(10), 2916. https://doi.org/10.3390/su11102916

Ghaderi, Z., Mirzapour, M., Henderson, J. C., \& Richardson, S. (2019). Corporate social responsibility and hotel performance: A view from Tehran, Iran. Tourism Management Perspectives, 29, 41-47. https://doi.org/10.1016/j.tmp.2018.10.007

González-Rodríguez, M.R., Martín-Samper, R.C., Köseoglu, M.A., \& Okumus, F. (2019). Hotels' corporate social responsibility practices, organizational culture, firm reputation, and performance. J Journal of Sustainable Tourism, 27(3), 398-419. https://doi.org/10.1080/09669582.2019.1585441

Hamid, M.A., Isa, S.M., \& Kiumarsi, S. (2020). Sustainable tourism practices and business performance from the tour operators' perspectives. Anatolia, 1-10. https://doi.org/10.1080/13032917.2020.1830135

Harjoto, M.A., \& Salas, J. (2017). Strategic and institutional sustainability: corporate social responsibility, brand value, and Interbrand listing. Journal of Product Brand Management. https://doi.org/10.1108/JPBM-07-2016-1277

Hughes, E., \& Scheyvens, R. (2018). Development alternatives in the Pacific: How tourism corporates can work more effectively with local communities. Tourism Planning \& Development, 15(5), 516-534. https://doi.org/10.1080/21568316.2018.1478881

Jamal Mohammad, S., Al-Haddad, L., Safdar Sial, M., \& Wan, P. (2020). corporate social responsibility and tourism industry : stakeholders approach . GeoJournal of Tourism and Geosites, 30, 913-916. https://doi.org/10.30892/gtg.302spl18-522

Jermsittiparsert, K., Joemsittiprasert, W., \& Phonwattana, S. (2019). Mediating Role of Sustainability Capability in Determining Sustainable Supply Chain Management in Tourism Industry of Thailand. International Journal of Supply Chain Management, 8(3), 47-58.

Karim, R.A., \& Islam, M.W. (2020). assessing customer demand and Customer satisfaction through social and enviromental practices in the hotel sector of Bangladesh. GeoJournal of Tourism and Geosites, 30(2spl), 843-851. https://doi.org/10.30892/gtg.302spl09-513

Kim, S.B., \& Kim, D.Y. (2016). The influence of corporate social responsibility, ability, reputation, and transparency on hotel customer loyalty in the U.S.: a gender-based approach. SpringerPlus, 5(1), 1537. https://doi.org/10.1186/s40064-016-3220-3

Kularatne, T., Wilson, C., Månsson, J., Hoang, V., \& Lee, B. (2019). Do environmentally sustainable practices make hotels more efficient? A study of major hotels in Sri Lanka. Tourism Management, 71, 213-225. https://doi.org/10.1016/j.tourman.2018.09.009

Landau, T. (2020). Action and progress on sustainability challenges: case examples from Marriott, Booking and Soneva. Worldwide Hospitality and Tourism Themes. https://doi.org/10.1108/WHATT-06-2020-0042

Levitt, T. (1958). The dangers of social-responsibility. J Harvard business review, 36(5), 41-50

Liu, F., Liu, Y., Mo, Z., Zhao, Z., \& Zhu, Z. (2019). How CSR influences customer behavioural loyalty in the Chinese hotel industry. Asia Pacific Journal of Marketing and Logistics. doi: https://doi.org/10.1108/APJML-04-2018-0160

Liu, F., Wang, X., Tian, X., \& Tang, Y. (2017). The effect of corporate social responsibility on hotel employees' work outcomes: The mediating role of organizational identification. Paper presented at the 2017 International Conference on Service Systems and Service Management.

Marin-Pantelescu, A., Tăchiciu, L., Căpuşneanu, S., \& Topor, D.I. (2019). Role of tour operators and travel agencies in promoting sustainable tourism. $J$ Amfiteatru Economic, 21(52), 654-669. https://doi.org/10.24818/EA/2019/52/654

Mariño-Romero, J.M., Hernández-Mogollón, J.M., Campón-Cerro, A.M., \& Folgado-Fernández, J.A. (2020). Corporate Social Responsibility in Hotels: A Proposal of a Measurement of its Performance through Marketing Variables. J Sustainability, 12(7), 2961. https://doi.org/10.3390/su12072961

Martinez Garcia de Leaniz, P., Herrero Crespo, A., \& Gómez López, R. (2018). Customer responses to environmentally certified hotels: The moderating effect of environmental consciousness on the formation of behavioral intentions. Journal of Sustainable Tourism, 26(7), 1160-1177. https://doi.org/10. $1080 / 09669582.2017 .1349775$

McWilliams, A., \& Siegel, D. (2001). Corporate social responsibility: A theory of the firm perspective. J Academy of management review, 26(1), 117-127. https://doi.org/10.5465/AMR.2001.4011987

Mohammed, A., \& Rashid, B. (2018). A conceptual model of corporate social responsibility dimensions, brand image, and customer satisfaction in Malaysian hotel industry. Kasetsart Journal of Social Sciences, 39(2), 358-364. https://doi.org/10.1016/j.kjss.2018.04.001

Montiel, I. (2008). Corporate social responsibility and corporate sustainability: Separate pasts, common futures. J Organization Environment, 21(3), 245-269. https://doi.org/10.1177/1086026608321329

Moon, J., Anastasiadis, S., \& Viganò, F. (2009). The potential of CSR to support the implementation of the EU sustainability strategy: editorial introduction. $J$ Business Ethics: A European Review, 18(3), 268-272. https://doi.org/10.1111/j.1467-8608.2009.01562.x

Moratis, L., \& Cochius, T. (2017). ISO 26000: The business guide to the new standard on social responsibility. Routledge.

Otoo, F.E., Senbeto, D.L., \& Demssie, M.A. (2020). Social and Environmental Responsibility among Inbound Tour Operations in Hong Kong. J Journal of China Tourism Research, 1-18. https://doi.org/10.1080/19388160.2020.1798319

Paskova, M., \& Zelenka, J. (2019). How crucial is the social responsibility for tourism sustainability? J Social Responsibility Journal. https://doi.org/10.1108/SRJ-03-2018-0057

Porter, M.E., \& Kramer, M.R. (2006). The link between competitive advantage and corporate social responsibility. J Harvard business review, 84(12), 78-92.

Rego, A., Cunha, M.P. e., \& Polónia, D. (2015). Corporate Sustainability: A View From the Top. Journal of Business Ethics, 143(1), 133-157. https://doi.org/10.1007/s10551-015-2760-8

Richards, P., \& Font, X. (2019). Sustainability in the tour operator-ground agent supply chain. J Journal of Sustainable Tourism, 27(3), 277-291. https://doi.org/10.1080/09669582.2018.1560451

Saarinen, J. (2014). Critical sustainability: Setting the limits to growth and responsibility in tourism. Sustainability, 6(1), 1-17. https://doi.org/10.3390/su6010001

Sariskumar, N., \& Bhavan, T. (2018). The impact of responsible tourism on destination sustainability and quality of life in Passikudah tourism destination. International Journal of Social Science and Economic Research, 3(11), 5933-5959.

Serra-Cantallops, A., Peña-Miranda, D.D., Ramón-Cardona, J., \& Martorell-Cunill, O. (2018). Progress in research on CSR and the hotel industry (20062015). Cornell Hospitality Quarterly, 59(1), 15-38. https://doi.org/10.1177/1938965517719267

Strasdas, W. (2019). Corporate Responsibility Among International Ecotourism and Adventure Travel Operators. In D. Lund-Durlacher, V. Dinica, D. Reiser, \& M.S. Fifka (Eds.), Corporate Sustainability and Responsibility in Tourism (pp. 143-161). Cham: Springer International Publishing.

Tepelus, C. (2019). New Frontiers for Sustainability in Travel and Tourism - Corporate Responsibility on Combating Global Human Trafficking. In D. Lund-Durlacher, V. Dinica, D. Reiser, \& M.S. Fifka (Eds.), Corporate Sustainability and Responsibility in Tourism (pp. 51-63). Cham: Springer International Publishing.

Walsh, P.R., Dodds, R., \& Environment, t. (2017). Measuring the choice of environmental sustainability strategies in creating a competitive advantage. $J$ Business Strategy, 26(5), 672-687. https://doi.org/10.1002/bse.1949

Yadav, R., Dokania, A.K., \& Pathak, G.S. (2016). The influence of green marketing functions in building corporate image. International Journal of Contemporary Hospitality Management. https://doi.org/10.1108/IJCHM-05-2015-0233

Yeh, S.S., Ma, T., \& Huan, T.C. (2016). Building social entrepreneurship for the hotel industry by promoting environmental education. J International Journal of Contemporary Hospitality Management. https://doi.org/10.1108/IJCHM-03-2014-0122

Yılmaz, Y., Üngüren, E., \& Kaçmaz, Y.Y. (2019). Determination of Managers' Attitudes Towards Eco-Labeling Applied in the Context of Sustainable Tourism and Evaluation of the Effects of Eco-Labeling on Accommodation Enterprises. J Sustainability, 11(18), 5069. https://doi.org/10.3390/su11185069

*** Alarabiya.net. (2018). Saudi city of Al-Ahsa named 'Capital of Arab Tourism' for 2019. Retrieved from https://english.alarabiya.net/en/life-style/traveland-tourism/2018/12/12/Saudi-Al-Ahsa-named-Capital-of-Arab-Tourism-for-2019. Last Access: September 01, 2020. 